\title{
AMRTA-X: GRASP KINEMATIC ANALYSIS DURING MYOELECTRIC PREHENSION ORTHOSIS AND BODY POWERED PREHENSION ORTHOSIS'S USAGE ON BRACHIAL PLEXUS INJURY PATIENTS
}

\author{
Fundhi Khrisna AP ${ }^{1 *}$, RA Meisy Andriana ${ }^{1}$, Reni H Masduchi ${ }^{1}$, IP Alit Pawana ${ }^{1}$ \\ ${ }^{1}$ Department of Physical Medicine and Rehabilitation, Faculty of Medicine, Universitas Airlangga, Dr Soetomo \\ Academic Hospital, Surabaya, Indonesia
}

\begin{abstract}
Brachial Plexus Injury (BPI) results in decreased motor function in upper extremity and leads to reduced hand grasping movement. Orthotic prehension is designed to create artificial grasp movements in paralyzed hand. This study was to compare grasp kinematic improvement between body powered and myoelectric prehension orthosis usage in patients with BPI. This study was a single group without control and post test with experimental study. The subjects of the study $(n=11)$ were brachial plexus injury patients with non-functional hand strength. Joint motion and angular velocity of metacarpophalangeal (MCP) and proximal interphalangeal (PIP) joint of index finger were evaluated. There was an improvement in joint motion and angular velocity after both orthosis usage. Joint motion in MCP and PIP, Angular velocity in MCP were not significantly different between myoelectric and body powered and myoelectric prehension orthosis usage. PIP angular velocity improvement were better after body powered prehension orthosis usage $(p=0.03)$.In conclusion, body powered and myolectric prehension orthosis usage improved kinematic parameter of index finger's MCP and PIP joint. PIP angular velocity was better after body powered prehension orthosis usage.
\end{abstract}

Keywords: kinematic analysis; brachial plexus injury; body powered prehension orthosis; myoelectric prehension orthosis

\section{ABSTRAK}

Cedera Pleksus Brakhialis (CPB) menyebabkan penurunan fungsi motorik ekstremitas atas dan mengganggu gerakan menggenggam. Ortosis prehension dirancang untuk menciptakan gerakan menggenggam buatan pada tangan yang mengalami kelumpuhan. Perbandingan perbaikan kinematika gerakan menggenggam antara penggunaan ortosis prehension body powered dengan ortosis prehension myoelektrik pada subyek penderita CPB. Studi ini adalah studi eksperimental single group, post test only. Subyek penelitian $(n=11)$ adalah pasien $C P B$ dengan kekuatan tangan non-fungsional $(M M T<3)$. Analisis kinematic dilakukan dengan mengevaluasi pergerakan dan kecepatan sudut sendi metacarpophalangeal (MCP) dan interphalangeal proksimal (PIP) jari telunjuk pada proses menggenggam. Terdapat perbaikan pergerakan dan kecepatan sudut sendi setelah penggunaan kedua jenis ortosis. Pergerakan sendi MCP dan PIP, serta kecepatan sudut sendi MCP tidak berbeda signifikan antara penggunaan kedua jenis ortosis. Peningkatan kecepatan sudut PIP lebih baik setelah penggunaan orthosis prehension body powered $(p=0,03)$. Sebagai simpulan, penggunaan ortosis prehension body powered dan myolektrik dapat meningkatkan parameter kinematik pada sendi MCP dan PIP jari telunjuk saat gerakan menggenggam. Perbaikan kecepatan sudut sendi PIP lebih baik setelah penggunaan ortosis prehension body powered.

Kata kunci: analisis kinematik; cedera pleksus brakialis; ortosis prehension body powered; ortosis prehension myoelektrik

\section{Correspondence:}

pISSN:2355-8393 • eISSN: 2599-056x • doi: 10.20473/fmi.v57i1.9035

- Fol Med Indones. 2020;57:27-33 • Received 20 Jul 2018 • Accepted 10 Jan 2019

- Open access under CC-BY-NC-SA license • Available at https://e-journal.unair.ac.id/FMI/

\section{INTRODUCTION}

Strong and sudden trauma that affects the shoulder region may result in damage to the shoulder and other structures that surrounds it, including muscles, fascia, skin, bones, and neuromuscular structures. In neuromuscular damage, the brachial plexus may be affected by this trauma. The brachial plexus injury 
(BPI) is a lesion on nerve tissue originating from the 5 th cervical roots to the 1 st thoracic root (C5-Th1). These lesions carry consequences, occurrence of neurological deficits in various structures that innervated by these nerve roots (Kang \& Wolfe 2011, Kelly \& Leonard 2012).

The incidence of BPI increased every year in Dr. Soetomo Academic Hospital Surabaya. Most of all were males $(86 \%)$ in the 21-30 years old (37\%). The most frequent injury mechanisms were motorcycle accidents $(90 \%)$, and the right side of injury was the right side $(77 \%)$. The levels of injury were $24 \%$ C5-6 postganglionic, $19 \% \quad \mathrm{C} 5-7$ postganglionic, $3 \%$ postganglionic $\mathrm{C} 8-\mathrm{T} 1,54 \% \mathrm{C} 5-\mathrm{T} 1$. In the complete $\mathrm{BPI}$, the postganglionic $\mathrm{C} 5-7$ and preganglionic $\mathrm{C} 8-\mathrm{T} 1$ combinations occurred in $33 \%$ of cases (Rachmawati et al 2016, Suroto 2011, Suroto 2015).

Generally, human hands play an important role in human interaction with the environment. In BPI, motor disturbances can result in loss of grip strength and hand function. According to data between January 2005 December 2009 in Dr. Soetomo, from 14 patients postoperative BPI, 7 patients had a motor power with more than or equal to 3 , and 7 patients had muscle strength less than 3 (Kelly \& Leonard 2012, Rachmawati et al 2016, Gustus et al 2012, Suroto 2011).

Brachial Plexus Injury (BPI) causes impaired motor and sensory function in the upper extremity. Impaired motor function in the shoulder, elbow and wrist caused disruption of the ability of stabilization, positioning and placement of the upper motion. While impaired motor function in both of extrinsic and intrinsic hand muscle caused disruption of hand prehension ability. The combination of all of those impairment added with exteroceptive and proprioceptive sensory dysfunction caused hand dexterity disruption (Jones 1996, Wardhani et al 2011).

In the BPI rehabilitation program, the use of shoulderelbow-wrist orthosis improves the stabilization, positioning and placement of upper extremity in functional position. Meanwhile, the use of prehension orthosis is intended to improve the ability of hand prehension. Although in practice, the use of prehension orthosis in Dr. Soetomo Academic Hospital for the BPI cases had never been given (Wardhani et al 2011, Bengtson \& Shin 2008, Lunsford \& DiBello 2008, Smania et al 2012, Hapsari et al 2017). In this case, there are two types of prehension orthosis; body powered prehension orthosis is prehension orthosis that used other healthy part of body to empower prehension ability. On the other hand, an externally powered prehension orthosis uses external source to create artificial grasp action (Lunsford \& DiBello 2008).

This study intended to compare kinematic improvement effect after body powered and myoelectric prehension orthosis usage in BPI patient. Body powered prehension orthosis that was used was a shoulder-driven prehension orthosis with the same principle design as in Lehneis publication. Thumb was fixated in an opposition position to the 2nd and 3rd fingers; the 2nd and 3rd fingers are driven by voluntary closed mechanical system through a cable drawn by the contralateral side through a shoulder harness (Lehneis 1968, Michael \& Nunley 1992, Lunsford \& DiBello 2008).

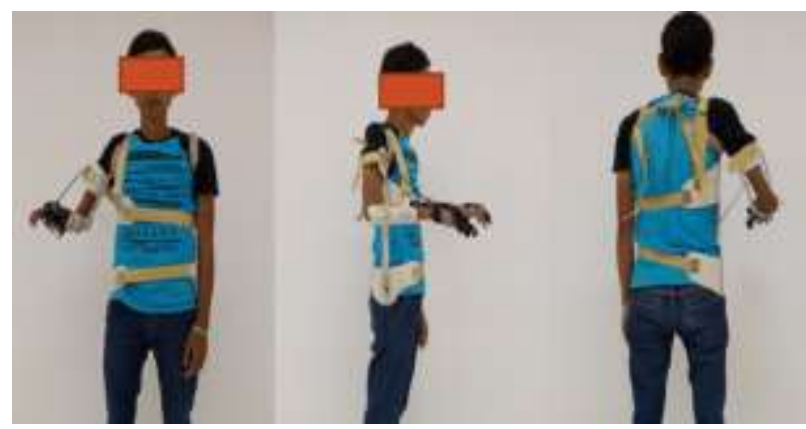

Figure 1. Body powered (shoulder driven) prehension orthosis installed on subject

Myoelectric prehension orthosis that were used were developed by the Department of Physical Medicine and Rehabilitation, Faculty of Medicine, Universitas Airlangga - Dr. Soetomo Academic Hospital. This myoelectric signal were taken from electrode that were placed over Platysma and Sternocleiodmastoideus muscle and processed later on surface EMG (sEMG) hardware (Myoware and Teensy board) and Arduino based-on software developed by the Faculty of Biomedical Technic of Science and Technology,Universitas Airlangga. The energy source for High torque motor servo and sEMG were $5 \mathrm{~V}$ Battery $7500 \mathrm{mAH}$. The mechanical components were 3D printed polylactic acid (PLA), and designed to enable the orthosis to make a three-jaw chuck position. This orthosis is a development of the Powered Dynamic Hand Orthosis (PDHO) (Lehneis 1968, Brown \& Roberts 2008, Fundhi et al 2016, Geethanjali 2016, Saharan et al 2017, Salamat et al 2017, Pawana 2016).

Kinematic parameters that were evaluated were joint movement and angular velocity at metacapophalangeal (MCP) and proximal interphalangeal (PIP) joint of index finger. Both of it were two of upmost kinematic parameters being analyzed.The kinematic analysis were conducted by using software Kinovea that had a quality, validity and reliability for measuring motion analysis 
(Charmant 2017, Chen et al 2015, Cordella et al 2014, Grigg et al 2017, Puig-Divi et al 2017, Mohamed 2015).

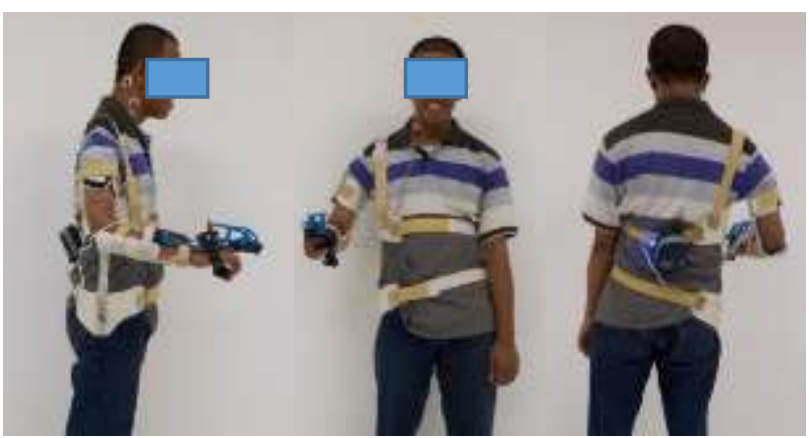

Figure 2. Myoelectric prehension orthosis installed on subject.

\section{MATERIALS AND METHODS}

In this single group without control, post-test research design was conducted on 11 patients with right brachial plexus injury in Medical Rehabilitation Installation of Dr. Soetomo Academic Hospital that fulfilled inclusion and exclusion criteria and recruited as research subjects. The inclusion criteria were right brachial plexus injury with hand muscle strength less than 3 , could understand and followed instructions, agreed to be the subject of research as well as following the entire series of research by signing informed consent form. The exclusion criteria were limitation of range of motion that inhibited orthosis installation, weakness of the left shoulder muscles, upper extremity acute inflammation, upper limb skin lesions, the size of the orthosis that did not match the suject body size. The subjects would be ruled out from the study if they developed an allergic reaction to the orthosis or could not complete the entire series of studies.

Table 1. Baseline characteristic

\begin{tabular}{ll}
\hline Character & Value \\
\hline $\mathrm{N}$ & 11 \\
$\mathrm{Sex}$ & Male $11(100 \%)$ \\
Age (years) & $27,18 \pm 5,95$ \\
Height $(\mathrm{cm})$ & $166,45 \pm 4,61$ \\
Weight $(\mathrm{kg})$ & $64.91 \pm 10,11$ \\
$\mathrm{BMI}(\mathrm{kg} / \mathrm{m} 2)$ & $23,36 \pm 3,44$ \\
BPI side & Right side $11(100 \%)$ \\
Root affected & Total C5-Th1 11 (100\%) \\
Degree of lesion & Complete $10(91 \%)$ \\
Duration (years) & $3,8 \pm 2,74$ \\
BPI's surgery history & FFMT 8 $(72,7 \%)$ \\
Rehabilitation program & Routinely $9(81,8 \%)$ \\
\hline
\end{tabular}

All subjects used shoulder-elbow orthosis to eliminate shoulder and elbow motoric disturbance. Then, they used both types of prehension orthosis alternately. First, subjects used body-powered prehension orthosis, and performed orthotic control exercises for 15 minutes. Then, grasp simulation video were recorded. After washout period for 7 days, the subjects used myoelectric prehension orthosis, and performed orthotic control exercises for 15 minutes. Then, grasp simulation video were recorded again. All videos were recorded with Sony Handycam HDR-CX240E in special grasp simulation platform. Then, these recordings were kinematically analyzed with Kinovea ver. 0.8.26.
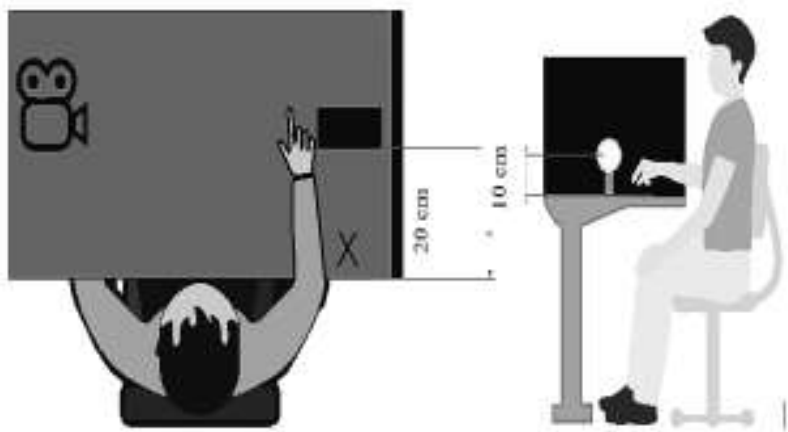

Figure. 3. Grasp simulation special platform.

The subject were instructed to grasp the $3 \mathrm{~cm}$-diameter cylinder three times. The fastest grasp was being analyzed. All of the data were collected and analyzed using SPSS version 17 software. This study was ethically approved by Health Research Ethical Comittee of Dr. Soetomo Academic Hospital Surabaya.

\section{RESULTS}

The study involved 11 male, right total BPI, age range of 22-36 years. All subjects were total BPI patients, 91\% had complete lesions, 55\% BPI at trunk level, 91\% had BPI due to motorcycle accidents, $82 \%$ had undergone free functioning muscle transfer (FFMT) operation, performed routine rehabilitation, BPI occurs between 4 months - 10 years, and all subjects have intrinsic and non-functional hand muscle strength (Table 1).

The initial and final angle of the MCP joint showed that there was no significant difference between the use of body-powered prehension orthosis with myoelectric ortosis. While in the initial and final angle parameters PIP showed that there was a significant difference between the use of body-based prehension orthosis with myoelectric ortosis. In the joint angle motion parameters, myoelectric prehension orthosis did not differ significantly in the MCP and PIP joint angle 
motion parameters compared to the body powered orthosis (Table 2).

The joint angular velocity parameters showed that body powered prehension orthosis is significantly superior than compared with myoelectric prehension orthosis in the PIP angular velocity parameter, while in the MCP angular velocity parameter, body powered prehension orthosis did not differ significantly from myoelectric prehension orthosis (Table 2).

\section{DISCUSSION}

This study was the first experimental study that compared between body powered prehension orthosis and myoelectric prehension orthosis usage in BPI subjects. There were some literatures that discussed prehension orthosis usage in BPI, but no one conducted any comparison between two types of prehension orthosis. Browns and Slack only mentioned externally powered prehension orthosis usage in BPI, while Michael and Lehneis mentioned body powered prehension orthosis (Brown \& Roberts 2008, Slack \& Berbrayer 1992, Michael \& Nunley 1992, Lehneis 1968).

The subjects of this study were 11 male patients with BPI aged 20-36 years. All subjects were total BPI patients, $91 \%$ had complete lesions, 55\% BPI at trunk level, 91\% had BPI due to motorcycle accidents, $82 \%$ had undergone free functioning muscle transfer (FFMT) operation, performed routine rehabilitation. The BPI occured between 4 months to 10 years, and all subjects had intrinsic and non-functional hand muscle strength (MMT <3) (table 1). The baseline characteristics of subjects were suitable with some literatures. The Department of Orthopedic and Traumatology Dr. Soetomo Academic Hospital mentioned that BPI sufferers were mostly male with young adult age (25-35 years old), and as suspects of motorcycle accidents. Narakas mentioned that $70 \%$ of BPI involved motorcycle traffic accidents. Rachmawati mentioned that half of BPI patients had functional upper muscle strength after FFMT procedures (Kang \& Wolfe 2011, Suroto 2011, Rachmawati et al 2016).

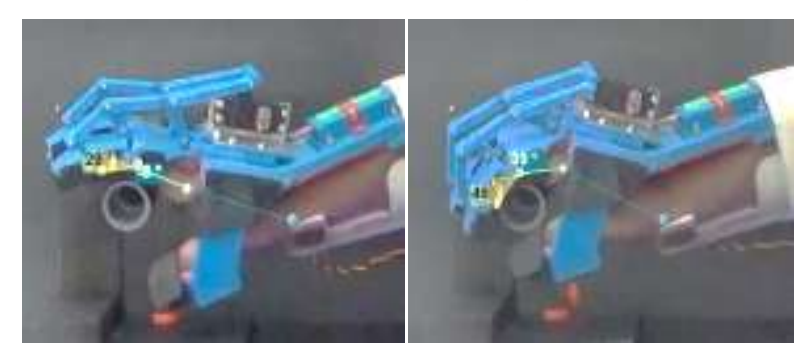

Figure 4. Kinematic analysis of MCP and PIP joints during myoelectric prehension orthosis usage. Left: initial position; Right: Final position

All subjects could complete the entire research phase until finished. It showed that subjects can adapt to the use of shoulder-angled orthosis as well as both types of prehension orthosis and had an ability to control the orthosis after a 15 minutes orthosis control exercise session. The use of orthosis prehension in the subject wasa form of environmental change that was intended to overcome the existing impairment on the subject. The ability to operate the orthosis showed a succesful adaptation to a new environment (WHO 2001, Johnson \& Mansfield 2014).

The ability of subject to control basic movement of prehension orthosis was also a great first step; considering that this was the first time he had experienced for using, feeling and controlling the orthosis. The ability of the subject to be able to move his hands back consciously had a great psychological impact, the change from being immobile limb to being mobile could be a big motivation for him. Instead of just moving the fingers, the control exercises also ensured that the orthosis worked well, where three jaw chuck movements that became the goal of finger movement were also achieved (Suroto 2011).

This study also showed that both orthosis design were safe to be used since there were no major or fatal side effect. The side effect that occured in this study was one subject being exhausted after body powered orthosis usage and another one subject felt uncomfortable in her neck and face after myoelectric prehension orthosis usage. 
Table 2. Kinematic parameter comparison of MCP and PIP joint

\begin{tabular}{|c|c|c|c|c|c|c|c|}
\hline \multirow{2}{*}{ Kinematic Parameter } & \multirow[t]{2}{*}{$\mathrm{n}$} & \multicolumn{2}{|c|}{ Body Powered Orthosis } & \multicolumn{2}{|c|}{ Myoelektric Orthosis } & \multirow[t]{2}{*}{$p$} & \multirow[t]{2}{*}{ Sig. } \\
\hline & & Value & SD/Range & Value & SD/Range & & \\
\hline MCP initial angle $\left({ }^{\circ}\right)$ & 11 & -14 & $-36-(-5)$ & -8 & $-54-(-4)$ & $0,857^{\mathrm{b}}$ & \\
\hline MCP final angle $\left({ }^{\circ}\right)$ & 11 & 5 & $-25-28$ & 13 & $-50-30$ & $0,350^{\mathrm{b}}$ & \\
\hline MCP joint movement $\left({ }^{\circ}\right)$ & 11 & 22 & 7,27 & 25 & 10,25 & $0.441^{\mathrm{a}}$ & \\
\hline PIP initial angle $\left({ }^{\circ}\right)$ & 11 & 50 & 11,24 & 22 & 10,81 & $0,000^{\mathrm{a}}$ & $* *$ \\
\hline PIP final angle $\left(^{\circ}\right)$ & 11 & 61 & $42-77$ & 31 & $21-78$ & $0,04^{\mathrm{b}}$ & ** \\
\hline PIP joint movement $\left({ }^{\circ}\right)$ & 11 & 11 & $5-31$ & 14 & $6-42$ & $0,181^{\mathrm{b}}$ & \\
\hline MCP angular velocity ( $\%$ s) & 11 & 44 & 22,78 & 33 & 9,88 & $0,218^{\mathrm{a}}$ & \\
\hline PIP angle velocity $(\% / s)$ & 11 & 24 & $20-80$ & 17 & $7-43$ & $0,03^{\mathrm{b}}$ & ** \\
\hline
\end{tabular}

The joint movement comparison result suggests that there is an advantage in the mechanical design of myoelectric prehension orthosis, ie the presence of a second joint in the finger bar that allows flexion movement in the PIP joints to be minimal. But the superiority of the design brings another consequence, in which the size and mechanical design of myoelectric prehension orthosis becomes larger and more complex. In fact, in terms of successful performing the task of grasping, both types of orthosis is successfully solve it. Thus, when viewed from the side of effectiveness, a more simple design is certainly preferred. Bos also mentions that it should be a consideration in designing of a functional hand tool (in this case orthosis prehension) that less complex design but still give a good function (Bos, et al., 2016).

The results of the research on the parameters of joint movement of both types of orthosis show that there is movement of MCP joints of $22-25^{\circ}$ and PIP $11-14^{\circ}$ joints. With such a wide range of joint motion is still very far from the area of normal joint motion, only about 25\% (MCP joint) and 15\% (PIP joint). The joint movement is suitable with the Sancho-Bru research, which states that Holding a cylinder with a diameter of $64 \mathrm{~mm}$ movement need MCP joint flexion of $10.2^{\circ}$ and PIP joint flexion $37.6^{\circ}$. Hayashi mentioned that it is necessary to move the MCP joints at least $100^{\circ}$, which begins with extension $30^{\circ}$ and ends at flexion $70^{\circ}$ so that there is no disruption of hand function. Bain's research states that the functional joint extent required to perform 20 items of function tests holding Sollerman's hands for MCP joints is $19-71^{\circ}$ flexion (48\% of total joint joints of MCP joints) and PIP 23-87 joints (59\% total joint PIP). So, it can be predicted that with the use of both this study's orthosis, they wouldn't able to mimic normal hand function or complete the task of daily activity (Duncan, et al., 2013; Hayashi, et al., 2014; Bain, et al., 2015; Sancho-Bru, et al., 2014).

Other mechanical design problems for a good prehension orthosis include the space in the hand is narrow. This is a design challenge, because imperfect mechanical design will produce not perfect finger movements. Improper mechanical design may also results in joint misalignment in hand, which may lead to discomfort in users, rejection in use, even to pressure sore occurrence (Bos, et al., 2016).

Angular velocity parameter comparison result suggests that body powered prehension orthosis can work to close the grasp faster, the factor that causes the speed of orthosis prehension body powered angle can be faster is because the closing speed of the grip is produced through direct body movement transmission, in this case the shoulder adduction movement. Whereas in myoelectric prehension othosis, the angular velocity is limited by the inherent specifications of the electric motors used, the magnitude of the energy source voltage as well as the efficiency of the mechanical components of the orthoses. The restriction of shoulder adduction movement is a motor learning process that is still in its early stages, only through a 15 minute adaptation process during the exercise of orthotic control, and a brief adaptation process also makes the subject to ensure that gripping movements have succeeded only from visual feedback.

Goebl's research mentions that through regular and rigorous exercise, a neurostructural organization will produce a more efficient movement. The imperfection of the sEMG system and the added lack of mechanical feedback and relatively short training time will result in the subject's adaptation process with more difficult myoelectric prehension orthosis (Goebl and Palmer, 2013; Carey, et al., 2015; Bos, et al., 2016; Hitec Multiplex, 2018).

The resultant angular velocity produced by both types of orthosis is still far from the normal value mentioned by Chen's research which states that the normal male hand angle velocity at MCP joints is $12,16 \mathrm{rad} / \mathrm{s}$ equivalent to $696.95 \%$ and in the PIP joint $15,03 \mathrm{rad} / \mathrm{s}$ equivalent to $860,93 \%$ s. However, the speed of grasping it is still faster than the Dorenfeld's developmental orthosis that takes time to close the grip by $60^{\circ}$ in 4.17 seconds, or has an angular velocity of $14.3 \%$ s (Chen, et al., 2013; Dorenfeld, et al., 2013). 
In the study there are some limitations of research, namely: orthosis prehension body powered and myoelektrik only available in 1 size, whereas research subjects have variations of body size, so it is possible there is an orthosis that is not fit for the body size of the subject.

There is difficulty in the process of recognition of movement by using a marker, the marker can not be attached completely to the wick joints of the wrist, MCP, PIP and DIP because the design of mechanical systems and orthotic materials sometimes cover the axis of the joint

\section{CONCLUSION}

Body powered shoulder-driven prehension orthosis and myoelectric prehension orthosis usage improves kinematics parameters of MCP and PIP joints of the second finger on BPI grip movements. Body powered shoulder-driven prehension orthosis usage is no better than myoelectric prehension orthosis prehension in improving movement of the MCP and PIP joints also MCP joint angular velocity. Body powered shoulderdriven prehension orthosis usage is better than the use of myoelectric prehension orthosis in improving the angular velocity of the second PIP joint joint in the BPI grip movement.

\section{REFERENCES}

Bain GI, Polites N, Higgs BG, Heptinstall RJ, McGrath AM (2015). The functional range of motion of the finger joints. Journal of Hand Surgery (European Volume) 4, 406-411.

Bengtson KA, Shin AY (2008). Orthoses for brachial plexus injuries. In: Hsu JD, Michael J, Fisk J (eds). AAOS atlas of orthoses and assistive devices 4th ed, Missouri, Mosby, p 249-259).

Bos RA, Haarman CJW, Stortelder T, Nizamis K, Herder JL, Stienen AHA, Plettenburg DH (2016). A structured overview of trends and technologies used in dynamic hand orthoses. J NeuroEngineering Rehabil 13.

Brown DW, Roberts K (2008). Application of external power in brachial plexus injury management: a case study. Fredericton, Proceeding of the 2008 MyoElectric Controls/Powered Prosthetics Symposium, Fredericton, New Brunswick, Canada, August 13-15, 2008.

Carey SL, Lura DJ, Highsmith MJ (2015). Differences in myoelectric and body-powered upper limb prostheses: systematic literature review. JRRD 52, 247-262.
Charmant J (2017). Kinovea. Available from http://www.kinovea.org/en/forum/viewtopic.php?pid= 3796\#p3796. Accessed March 13, 2018.

Chen CH, Azari DP, Hu YH, Lindstrom MJ, Thelen D, Yen TY, Radwin RG (2015). The accuracy of conventional 2D video for quantifying upper limb kinematics in repetitive motion occupational tasks. Ergonomics 58, 2057-2066.

Chen FC, Appendino S, Battezzato A, Favetto A, Mousavi M, Pescarmona F (2013). Constraint study for a hand exoskeleton: human hand kinematics and dynamics. Journal of Robotics 2013.

Cordella F, Zollo L, Salerno A, Accoto D, Guglielmelli E, Siciliano B (2014). Human hand motion analysis and synthesis of optimal power grasps for a robotic hand. International Journal of Advanced Robotic Systems 11.

Dorenfeld E, Wolf R, Zeveska S (2013). Design of a powered hand orthosis. Worcester: Gordon Library Worcester Polytechnic Institute. Available from https://web.wpi.edu/Pubs/E-project/Available/Eproject-042513-

135953/unrestricted/Design_of_a_Powered_Hand_Ort hosis_MQP_Report.pdf. Accessed March 13, 2018.

Duncan SFM, Saracevic CE, Kakinoki R (2013). Biomechanics of the hand. Hand Clin 29, 483-492.

Fundhi KA, Pawana I, Masduchi R (2016). The Effect of Powered Dynamic Hand Orthosis (PDHO) usage to grip strength and hand function on brachial plexus injury's patient affected hand, Jakarta, Pertemuan Ilmiah Tahunan Perdosri.

Geethanjali P (2016). Myoelectric control of prosthetic hands: state-of-the-art review. Med Devices (Auckl) 9, 247-255.

Goebl W, Palmer C (2013). Temporal control and hand movement efficiency in skilled music performance. PLoS ONE.

Grigg J, Haakonssen E, Rathbone E, Orr R, Keogh J (2017). The validity and intra-tester reliability of markerless motion capture to analyse kinematics of the BMX Supercross gate start. Sports Biomech 17, 383-401.

Gustus A, Stillfried G, Visser J, Jorntell H, van der Smagt P (2012). Human hand modelling: kinematics, dynamics, applications. Biol Cybern 106, 741-755.

Hapsari R, Wardhani I, Pawana IP (2017). Perbandingan Efek Segera Pemakaian Hemisling Dan Ortosis Bahu Fungsional Terhadap Pengurangan Subluksasi Bahu Pada Penderita Cedera Pleksus Brakialis, Surabaya, Departemen Ilmu Kedokteran Fisik dan Rehabilitasi Fakultas Kedokteran Universitas Airlangga RSUD dr Soetomo.

Hayashi H, Shimizu H, Okomura S, Miwa K (2014). Necessary metacarpophalangeal joints range of motion to maintain hand function. Hong Kong Journal of Occupational Therapy 24, 51-55. 
Johnson SS, Mansfield E (2014). Prosthetic training: upper limb. Phys Med Rehabil Clin N Am 25(1), 133151.

Jones L (1996). 17 - Proprioception and its contribution to manual dexterity. Hand and Brain: The Neurophysiology and Psychology of Hand Movements, 349-362.

Kang L, Wolfe S (2011). Traumatic brachial plexus injuries. In: Skirven TM, Osterman L, Fedorczyk J, Amadio PC (eds). Rehabilitation of the hand and upper extremity 6th ed, Philadelphia, Elsevier Mosby, p 749.

Kelly BM, Leonard JA (2012). Rehabilitation concepts for adult brachial plexus injuries. In: Chung $\mathrm{KC}$, Yang LJS, McGillicuddy JE (eds). Practical management of pediatric and adult brachial plexus palsies, Philadelphia, Elsevier Saunders, p 301.

Lehneis HR (1968). Application of external power in orthotics. Available from http://www.oandplibrary.org/op/pdf/1968_03_034.pdf . Accessed March 13, 2018.

Lunsford TR, DiBello TV (2008). Principles and components of upper limb orthoses. In: Hsu JD, Michael JW, Fisk JR (eds). AAOS atlas of orthoses and assistive devices 4th ed, Philadelphia, Elsevier Mosby, p 179.

Michael J, Nunley J (1992). Special Considerations: Brachial Plexus Injuries: Surgical Advances and Orthotic/Prosthetic Management. In: Bowker JH, Michael JW, American Academy of Orthopaedic Surgeons (eds). Atlas of limb prosthetics: surgical, prosthetic, and rehabilitation principles, Rosemont, American Academy of Orthopedic Surgeons.

Mohamed AN (2015). A novice guide towards human motion analysis and understanding. Available from http://search.arxiv.org:8081/paper.jsp?r=1509.01074\& qid=1518441717991bas_nCnN_1754697412\&qs=A+ Novice+Guide+towards+Human+Motion+Analysis+a nd+Understanding. Accessed March, 13, 2018.

Pawana IP (2016). Aplikasi instrumentasi dalam kedokteran fisik dan rehabilitasi. Surabaya, Departemen Ilmu Kedokteran Fisik dan Rehabilitasi FK Unair- RS dr Soetomo.

Puig-Divi A, Padullés-Riu JM, Busquets-Faciaben A, Padullés-Chando X, Escalona-Marfil C, Marcos-Ruiz
D (2017). Validity and reliability of the kinovea program in obtaining angular and distance dimensions. Preprints 2017.

Rachmawati S, Subagyo, Arfianti L, Wardhani I (2016). Faktor yang mempengaruhi perbaikan motorik pasca pembedahan rekonstruksi functioning free muscle transfer pada pasien cedera pleksus brakhialis akibat trauma. Theses, Universitas Airlangga, Surabaya.

Saharan L, Sharma A, Andrade MJ, Baughman R, Tadesse Y (2017). Design of a 3D printed lightweight orthotic device based on twisted and coiled polymer muscle: iGrab hand orthosis, Oregon, Conference of Society of Photo-Optical Instrumentation Engineers (SPIE) Smart Structures and Materials + Nondestructive Evaluation and Health Monitoring (SS17).

Sancho-Bru J, Mora MC, Leon BE, Pérez-González A, Iserte JL, Morales A (2014). Grasp modelling with a biomechanical model of the hand. Comput Methods Biomech Biomed Engin 17, 297-310.

Slack M, Berbrayer D (1992). A myoelectrically controlled wrist-hand orthosis for brachial plexus injury: a case study. Journal of Prosthetics and Orthotics, 171-174.

Smania N, Berto G, Marchina EL, Melotti C, Midiri A, Roncari L, Zenorini A, Lanes P, Picelli A, Waldner A, Faccioli S, Gandolfi M (2012). Rehabilitation of brachial plexus injuries in adults and children. Eur $\mathbf{J}$ Phys Rehabil Med 48, 483-506.

Suroto H (2011). How to manage adult brachial plexus injuries? Current diagnosis and comprehensive treatment of brachial plexus injury, Surabaya, 1st National Symposium.

Suroto H (2015). Evaluation of nerve procedures and FFMT in adult BPI - the Surabaya experience. BMC Proc 9, A23.

Wardhani I, Kurniawati P, Qorib F (2011). Peran Rehabilitasi Dalam Penanganan Pre dan Paska Operasi Lesi Pleksus Brakhialis. Current Diagnosis and Comprehensive Treatment of Brachial Plexus Injury, Surabaya, 1st National Symposium.

World Health Organization (2001). International classification of functioning, disability and health (ICF). Geneva, WHO. 